The Labore Journal of Economics

Special Edition

\title{
Money Supply, Inflation and Economic Growth: Issues in Monetary Management in Pakistan
}

\section{Ashraf Janjua*}

\section{Introduction}

The experience of the State Bank of Pakistan (SBP) in conducting the monetary policy of the country over the years comprises a whole range of regimes. While the overall objectives of monetary policy have remained the same, policy contents - intermediate targets, choice of instruments and controls etc. - have varied considerably over the years.

\section{(I) 1948-59}

Given the conditions prevailing in 1948 the SBP adopted a monetarist approach so far as achievement of price stability was concerned. One of the objectives of money policy was to develop the various aspects of the financial sector particularly the banking system. In this context monetary policy gave importance to the asset side of the banking system. Thus, upto 1960 the bulk of monetary expansion was on account of credit to the government sector.

In the early years of the country's economic history the size of the private sector was small and banks were very conservative in lending. Thus, upto 1959-60 lending to the private sector was a relatively unimportant source of changes in money supply compared with deficit financing by the public sector.

\footnotetext{
* Dean, College of Business Management.

This article is the revised and updated version of the paper which the author presented at the First Annual Conference on the Management of Pakistan Economy organized by Lahore School of Economics, Lahore on April 28-30, 2005. Views in this article are those of the author and not necessarily of the CBM or Lahore School of Economics.
} 
Table -1

Rs. Million

\begin{tabular}{lcccccc}
\hline \multicolumn{1}{c}{ Period } & $\begin{array}{c}\text { Private } \\
\text { Sector }\end{array}$ & $\begin{array}{c}\text { Government } \\
\text { Sector }\end{array}$ & $\begin{array}{c}\text { Other } \\
\text { Items }\end{array}$ & $\begin{array}{c}\text { Total Bank } \\
\text { Credit }\end{array}$ & $\begin{array}{c}\text { Foreign } \\
\text { Sector }\end{array}$ & $\begin{array}{c}\text { Monetary } \\
\text { Assets }\end{array}$ \\
\hline $1950-51$ to & $257.2-$ & 1468.0 & 281.5 & 2006.7 & -573.0 & 1433.7 \\
$1954-55$ & $(12.8)$ & $(73.25)$ & $(14.0)$ & $(100)$ & & \\
$1955-56$ to & 724.9 & 1442.6 & -73.57 & $2094(100)$ & 287.0 & 2381 \\
$1959-60$ & $(23.95)$ & $(70.98)$ & $(5.07)$ & & & \\
\hline
\end{tabular}

Source: State Bank of Pakistan various publications. Figures in parenthesis are the percentage share in the total credit.

The demand for bank credit from the Public Sector emanated from the following factors:

1) Growing need of liquidity in the economy.

2) Government's heavy expenditure on the development of infrastructure.

3) Pakistan Industrial Development Corporation (PIDC) was setup to make up for investment in projects where the private sector was reluctant to enter.

4) Funds for commodity operations.

Percentage Share in Total Credit 1950-51 to 1959-60

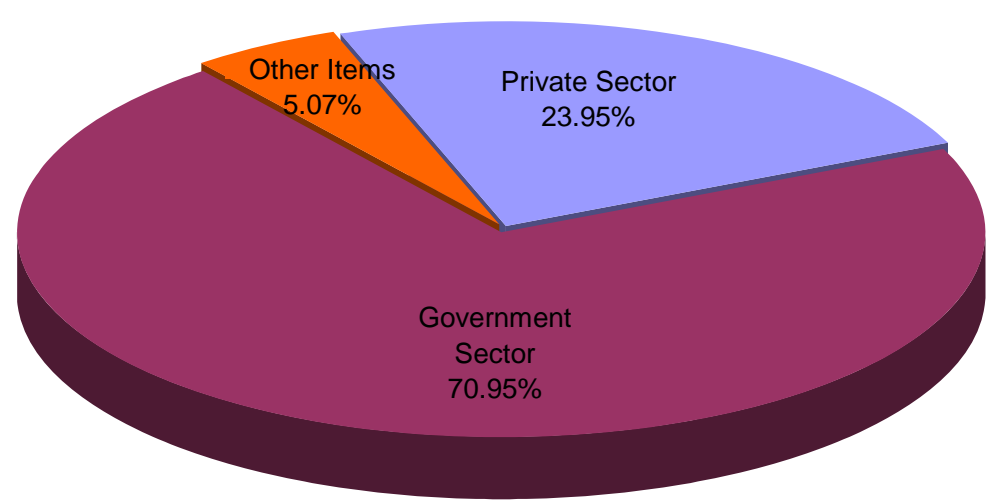


Given the underdeveloped financial system ${ }^{* *}$ including virtually nonexistent money market, the responsibilities of the State Bank during the early years of its existence (1948-59) went beyond the conventional functions of a Central Bank. These included rehabilitation of the banking system and ensuring its growth through helping the setting up of financial institutions, developing the money market and training bankers.

\section{(II) Monetary Policy 1960-72}

The year 1959-60 marked the beginning of a phase of liberalization and deregulation of the economy and substantial flow of resources from abroad. The Government's liberal economic policies met with an enthusiastic response from the private sector. Both the expansion in investment and production entailing liberalization enhanced demand for credit in the private sector.

With high growth rates of investment and production as well as large movements in the external accounts, policy changes were made by the State Bank to keep pace with these developments and adequately meet the genuine credit needs of the economy. An overview of the monetary and credit developments during 1959-60 to 1971-72 shows major changes in terms of policies, rate of expansion in bank credit and its sectoral distribution.

Table-2

Rs. Million

\begin{tabular}{lcccccc}
\hline \multicolumn{1}{c}{ Period } & $\begin{array}{c}\text { Private } \\
\text { Sector }\end{array}$ & $\begin{array}{c}\text { Sovernment } \\
\text { Sector }\end{array}$ & $\begin{array}{c}\text { Other } \\
\text { Items }\end{array}$ & $\begin{array}{c}\text { Total Bank } \\
\text { Credit }\end{array}$ & $\begin{array}{c}\text { Foreign } \\
\text { Sector }\end{array}$ & Monetary \\
\hline $1960-61$ to & 4524.4 & 1447.5 & -383.2 & 5588.7 & -412.7 & 5176 \\
$1964-65$ & $(81.0)$ & $(26.0)$ & $(-7.00)$ & $(100)$ & & \\
$1965-66$ to & 5539.4 & 4223.9 & -1480.2 & 8283.1 & 273.6 & 8557.3 \\
$1969-70$ & $(67.0)$ & $(51.0)$ & $(-18.0)$ & $(100)$ & & \\
$1970-71$ to & 2043.2 & 3573.8 & -2958.5 & 2658.5 & 235.3 & 2893.8 \\
$1971-72$ & $(77.0)$ & $(134.0)$ & $(-111.00)$ & $(100)$ & & \\
\hline
\end{tabular}

Figures in Parenthesis are percentage share in the total credit

\footnotetext{
** Financial system comprises (i) Regulatory authorities (ii) Banks and non-bank financial institutions (iii) financial markets: money, capital and foreign exchange markets and (iv) Financial infrastructure i.e. legal framework, accounting, auditing, Human resources and skill and information system etc.
} 
Percentage Share in Total Credit 1960-61 to 1969-70

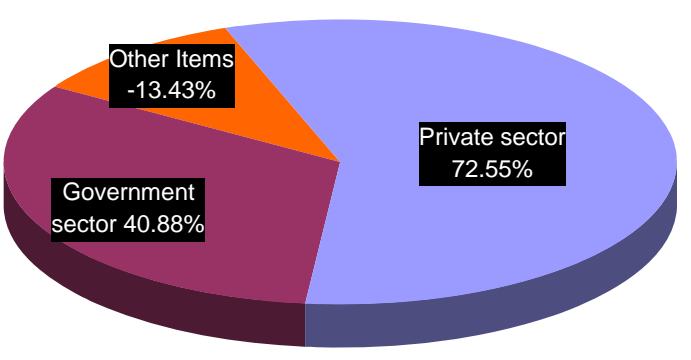

Percentage Share in Total Credit 1970-71 to 1971-72

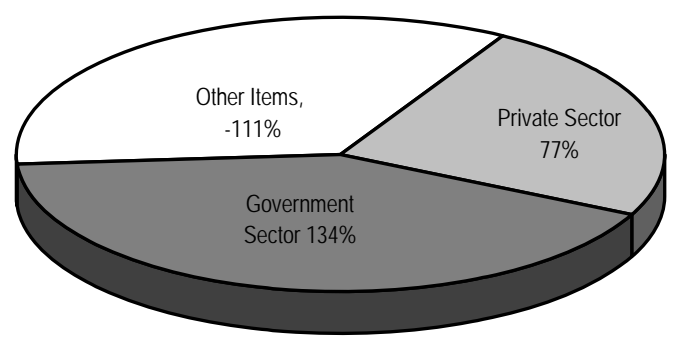

(III) Choice of Policy Instruments for Monetary Management 1948 - 72

\section{1) Interest Rate Policy}

During this period interest rate as an instrument of monetary policy was rarely used. The State Bank was of the view that the effectiveness of interest rate change in the economy was subject to many constraints. During 1949-50 - 1958-59 bank credit formed a small percentage of GDP. Therefore, the effects of changes in the Bank Rate were unlikely to be substantial. Also, it was viewed that other general credit control weapons would not be effective because of imperfections in markets. The banking system was not widespread and currency constituted a pre-dominant part of the Monetary Assets (M2)*.

\footnotetext{
${ }^{*} \mathrm{M}_{2}$ comprises (i) currency in circulation (ii) demand deposits with scheduled banks (iii) time deposits with the scheduled banks and (iv) other deposits with the State Bank. $\mathbf{M}_{1}$ comprises $\mathrm{M}_{2}$ minus time deposits of scheduled banks. $\mathrm{M}_{0}$, which is reserve money comprises (i) currency in circulation (ii) currency in the tills of scheduled banks, (iii) scheduled banks reserves with the State Bank and (iv) other deposits with the State Bank.
} 
Even during the price pressure between July, 1956 and June, 1958, the State Bank's view remained that a higher Bank Rate or restrictive monetary policy all by itself could not possibly offset the powerful expansionary impact of government operations because of the limited role that the Bank Rate played as a determinant of money supply.

Change in the Bank Rate from 3 to $4 \%$ on January 15, 1959 to supplement fiscal policy to check inflationary pressure had no effect on the level of bank advances and failed to exercise any influence to reduce consumption.

Up to 1972 the main thrust of the State Bank policy was based on the belief that any increase in the interest rate would adversely affect the investment activity. The Bank Rate was changed twice during this period i.e. from 4 to $5 \%$ on $6^{\text {th }}$ June, 1965 as a part of containing credit expansion in the private sector and from 5 to $6 \%$ after devaluation of the rupee on $11^{\text {th }}$ May, 1972 as a follow up measure to protect the benefits of devaluation.

Even in 1962-63 when credit to the private sector had expanded considerably the State Bank introduced the quota system and did not favor an increase in the Bank Rate because of the Bank's perceived adverse implications of such a measure for the country's economy.

\section{(VI) Regulations of Deposit and Advances Rates} the SBP.

During this period deposit and advances rates were also regulated by

\section{(V) Quota System and Cash Reserves Requirements}

As a part of containing credit expansion to a prudent level the State Bank introduced the Quota System on $1^{\text {st }}$ August 1963 . This was in respect of scheduled bank's entitlement to borrowing from the State Bank against government securities. Borrowing in excess of the quota was subjected to enhanced rate of interest.

Changes in the Reserve Requirements and the introduction of the Quota System were found to be ineffective in correcting the monetary situation. Both the government and the private sector continued to borrow heavily during 1963-64, and Monetary Assets expanded by $16.9 \%$ despite a contractionary influence of the external sector. Earlier, Monetary Assets had increased by $17.2 \%$ during $1962-63$. 
In January 1965 all types of borrowing were covered by the quota system including bank borrowing by the central and provincial governments. Banks' borrowing entitlement against government securities was reduced from $50 \%$ to $25 \%$. Borrowing in excess of the quota was subjected to graduated penal rates. Also, Reserve Requirements of scheduled banks were raised from $5 \%$ to $7.5 \%$ in two installments.

Notwithstanding these measures credit to the private sector continued to expand and the government's bank borrowing also increased following the 1965 war. As a result of a record expansion in Monetary Assets (M2) of Rs. 2036 million during 1965-66, imbalance between demand and supply put pressure on prices which increased by 5.7\% during 1965-66 and $10.3 \%$ during the following year.

However, credit demand from the private sector continued to expand. As a result, in the middle of 1967 the State Bank increased the Reserve Requirement to $6.25 \%$ and introduced a whole range of selective credit controls.

\section{(VI) Selective Credit Controls}

During 1959-72 the State Bank made extensive use of Selective Credit Controls to achieve the objective of monetary policy. Selective Credit Controls means action on the part of monetary authorities to control the flow of credit for particular purposes. Selective credit controls aim at channeling bank credit to socially desirable and economically useful purposes. As rightly pointed out by Richard Porter "selective credit controls are less devious and can be asserted without so many unpalatable side effects; for this reason they have been more acceptable as a policy tool of the State Bank.......”.

Selective Credit Controls pre-dominantly consist of changes in minimum margin requirements to be retained by banks on advances against various commodities, to various borrowers, ban on advances against selected commodities, margins against letters of credit etc.

\section{(VII) Monetary Policy and Movements in Prices 1948-72}

Broadly speaking, the entire period up to 1971-72 can be described as a period of relative price stability. The average price increase during the first Five-Year Plan (1955-56 to 1959-60) was 3.2\%, during the 
second Five-Year Plan (1960-61 to $1964-65)$ it was $2.3 \%$ and during the third Five-Year Plan (1965-66 to 1969-70) it was 4.5\%. This also included the only double digit increase in prices of $10.3 \%$ during 1966-67 which was the combined result of excessive monetary expansion during 1962-63 to $1965-66$ (the annual average of $16.5 \%$ compared with annual average growth rate of $7.65 \%$ ), poor food crops and interruption in the inflow of foreign assistance. The relative price stability over the years resulted from high growth rates, an average of $6.78 \%$ during the 10 year period between 1960-61 to 1969-70 and increase in the availabilities because of liberal import policy and deficit on current account. During the two turbulent years, 1970-71 and 1971-72, prices came under pressure as a combined result of demand pressure stemming from turbulent conditions and decline in growth rate to $1.2 \%$ during $1970-71$ which rose marginally to $2.3 \%$ during 1971-72.

The State Bank authorities constantly monitored the movement in prices for a possible policy change to contain inflationary pressures. Whenever the Bank felt necessary, measures were taken to contain demand through credit management. The State Bank kept two factors in view: The behavior of price movement in the country was determined by the agriculture sector which was susceptible to changes in weather conditions, and the pattern of consumption was changing significantly, particularly in urban and sub-urban areas because of a rise in per capita income. When the third Five-Year Plan (1965-66 - 1969-70) placed greater emphasis on heavy industries and infrastructure, the State Bank unified Cash Reserve Requirements $\left(25^{\text {th }}\right.$ July, 1963) and introduced the Quota System in respect of scheduled banks' borrowing from the State Bank against government securities.

The excessive monetary expansion was mainly accounted for by large scale deficit financing. The Third Five-Year plan had envisaged that deficit financing in the entire Plan period would remain within Rs. 1500 million. Actually, deficit financing during the Third Plan period amounted to Rs. 4350 million, (Rs. 4.35 billion), though both the growth rate and availability of aid were less than the original estimates".

The graph below depicts movements in $\mathrm{M}_{2} / \mathrm{y}$ ratio and inflation during 1950-51 and 1971-72. The graph shows that the biggest price increases always followed a peak in the $\mathrm{M}_{2} / \mathrm{y}$ ratio, with a variable time lag. 


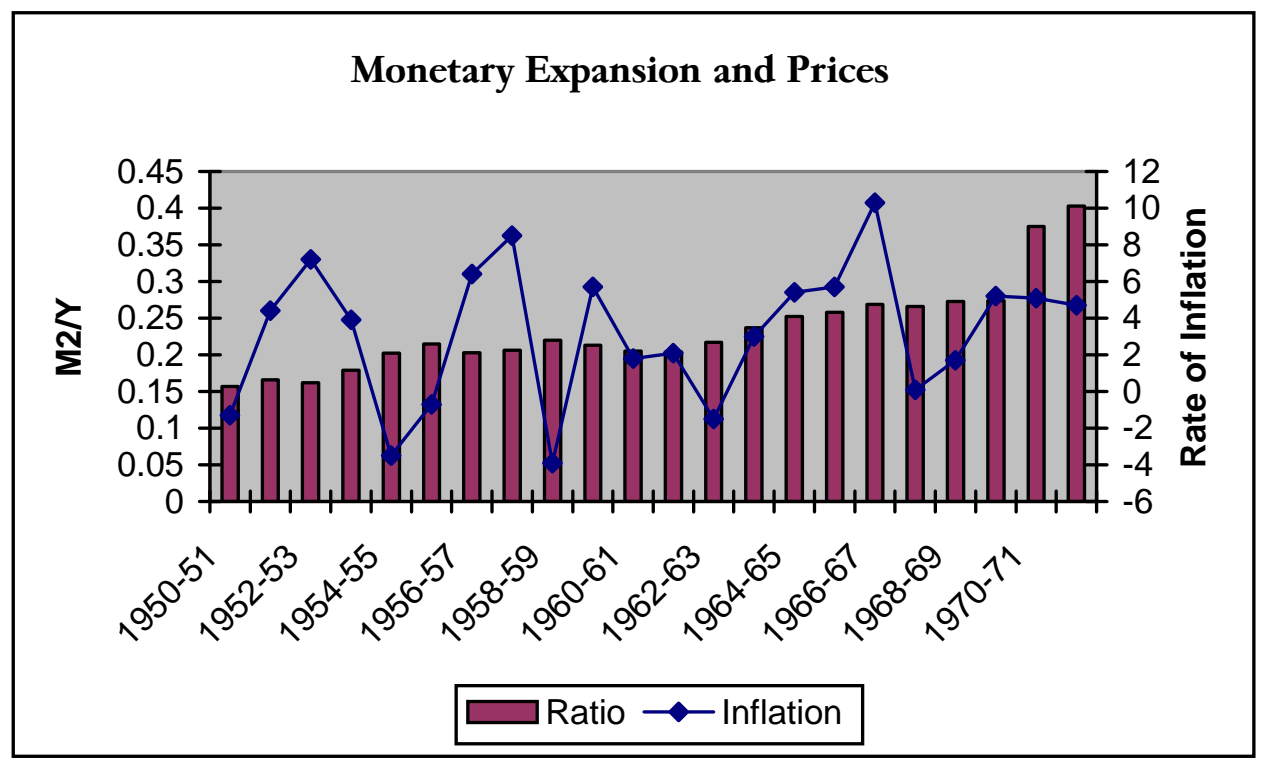

(VIII) Monetary Policy and Economic Growth -1948-72

Monetary policy's direct contribution to economic growth can be judged from its achieving the objectives of (i) increasing domestic savings (as a percentage of GNP), (ii) real investment and (iii) the rate of economic growth including special schemes to provide credit to otherwise neglected sectors. Indirect contribution means (i) maintaining relative price and exchange rate stability that should generate confidence among economic agents (ii) development of institutional framework for promoting savings and investment (iii) an efficient payments system and (iv) distribution of credit.

Various governments during this period set goals and adopted policies to expand exports in order to increase the import of capital goods and an increase in domestic savings. Various incentive schemes intended to promote both of these objectives were implemented from time to time. However, at no time did the government attempt either to increase public savings significantly by increasing taxation or to increase private savings by higher interest rates. The government tried to increase real investment as a share of GNP by means of an import policy that restricted imports of consumer goods, both by high tariffs and by import licensing and increase in the share of investment goods (and raw materials for investment goods industries) in total imports.

A policy of changing the composition of available goods in favor of investment goods relative to consumption goods - while at the same time not changing the composition of demand - would require an increase in the relative prices of consumer goods. 
During the period under review money supply increased at a rate that was larger than that consistent with price stability. Also, the government was not willing to let consumer prices rise and had always attempted to exert some influence on them. Until 1959/60, these attempts took the form of legal price controls and, in the case of food grains, requisitioning from farmers at fixed prices. With effect from 1959/60, the government relied more on increasing supplies as a means of holding consumer prices down.

It is obvious that the policy of holding consumer prices down by meeting any increases in demand at the controlled prices through imports and by permitting domestic consumers to bid away potential exports - was inconsistent with a policy of increasing the domestic savings rate and increasing the share of investment in GNP.

The following table shows savings ratios in Pakistan during 1959-90 $-1971-72$.

Table-3: Trends in Domestic Savings

\begin{tabular}{cccc}
\hline Year & GDP & Domestic Saving & \% of GDP \\
\hline $1959-60$ & 18257 & 2680 & 14.679301 \\
$1960-61$ & 20032 & 3073 & 15.340455 \\
$1961-62$ & 20919 & 3533 & 16.888953 \\
$1962-63$ & 22406 & 4513 & 20.141926 \\
$1963-64$ & 25157 & 5762 & 22.904162 \\
$1964-65$ & 28669 & 7111 & 24.803795 \\
$1965-66$ & 31690 & 6535 & 20.621647 \\
$1966-67$ & 36126 & 7465 & 20.663788 \\
$1967-68$ & 38985 & 6787 & 17.40926 \\
$1968-69$ & 41945 & 6888 & 16.421504 \\
$1969-70$ & 48298 & 8290 & 17.164272 \\
$1970-71$ & 51273 & 8761 & 17.086966 \\
\hline
\end{tabular}

Sharp increase in savings as a percentage of GDP during 1962-63 and 1966-67, a period of high growth rate, was due to liberal imports of capital goods enjoying a highly preferential exchange rate and high marginal rate of savings by the Corporate Sector. 
The Export Bonus Scheme (EBS), by virtue of providing preferential exchange rate for the import of investment goods, encouraged investment and growth. This, combined with inflow of aid till the 1965 war with India, a liberalized and deregulated environment, a law and order situation that was conducive to investment by the private sector, contributed to a high growth rate and impressive marginal rate of savings by the Corporate Sector.

\section{(IX) Monetary Policy 1972-88}

Monetary policy during this period was characterized by:

(1) Creation of National Credit Consultative Council (NCCC) and Annual Credit Plan, 1972

(2) Regimes of credit ceilings with effect from October 1973

(3) Directed, concessionary and mandatory credit targets

(4) Targets for fixed investment and exports

(5) Control on bank deposits and lending rates

Thus monetary policy, which prior to 1972 was essentially conducted through an indirect method of credit control, was now run by fiat. National Credit Consultative Council (NCCC) and Annual Credit Plan were introduced in 1972. It was realized in 1972 on the basis of past experience that use would need to be made of more direct methods of controlling the volume, the cost and allocation of credit in the economy. Hence a regime of credit ceilings was introduced in October 1973. In addition, the State Bank prescribed for commercial banks annual mandatory targets for production loans, tobacco marketing and loans both for production and development for small farmers. Simultaneously there were protected targets for fixed investments and refinancing of loans under locally manufactured machinery (LMM) and agro based activities.

Also subsidized/concessionary loans were given under various Special Financing Schemes introduced by the State Bank during 1972-73.

Before 1972 it had emerged that (a) there was concentration of credit (b) and interlocking of the ownership of assets structure: industrial enterprises, banking insurance, shipping etc. The Bhutto Government, as a part of policy objectives to reduce income inequalities and to bring about a more just and egalitarian social order, introduced a comprehensive banking 
reforms program in May 1972. These banking reforms emphasized two aspects: (1) End of interlocking of banks and industry etc. (2) distribution of capital to be spread widely. This was recommended because when a commercial or industrial undertaking has large interest in a bank it manages to get easy access to credit facilities of the State Bank which would lead to further concentration of wealth.

\section{(X) Choice of Policy Instruments - 1972-88}

While the credit ceilings regime was by itself the main instrument of credit management, use was also made of other policy instruments.

\section{i. The Bank Rate}

By 1972, it was realized by the State Bank authorities that the past policy of not making significant changes in the Bank Rate, because of its likely adverse impact on demand for credit, needed to be revisited, despite the fact that changes in the Bank Rate between 1948 and May 11, 1972, generally failed to have the desired effect on credit expansion. Realizing that availability of bank credit mattered more than its cost, the Bank authorities became more flexible on the interest rate policy.

On May 11, 1972, the Bank Rate was also raised from 5 to $6 \%$ accompanying the devaluation decision. Although subsequently the Bank Rate was gradually raised to $10 \%$ and the deposit rates and the lending rates of scheduled banks were also raised, the rates of credit and monetary expansion accelerated during this period.

\section{ii. Selective Credit Controls}

These were used mainly to (a) direct the flow of credit to selected sectors and sub-sectors (b) to prevent the build-up of inventories particularly of commodities of daily use and (c) serve as an adjunct to import policy.

\section{iii. Statutory Liquidity Ratio SLR}

The Statutory Liquidity Ratio (SLR) was raised from $25 \%$ on $1^{\text {st }}$ September, 1967 to $30 \%$ on $6^{\text {th }}$ June, 1973 . It was further raised to $35 \%$ on $16^{\text {th }}$ August, 1973, to absorb a part of excess liquidity entailing large scale monetary expansion in the preceding year. But raising the SLR could not control the overall volume of credit as it could only influence its distribution between the public and private sectors, or else would result in crowding out of the private sector if targeted overall credit expansion was kept unchanged. 


\section{(XI) Credit Planning and Credit Ceilings: An Appraisal}

At the macro level, credit budgeting was, by and large, an effective instrument of monetary policy in terms of providing adequate liquidity for the development process without generating unmanageable price increases. Also, credit budgeting was very helpful in directing bank credit to previously neglected priority sectors of the economy. However, the experience had shown that the technique of credit ceilings was not without problems. For one, credit ceilings tended to adversely affect commercial banks' incentive to mobilize deposits. In the same context, credit ceilings also inhibited competition among banks and gave rise to complications arising from differences in banks' types of business, size and current rate of growth. Credit ceilings severely limited a bank's ability to respond flexibly to demands of the economy. It was also observed that before the upward revision of the rate of penalty, some commercial banks were tempted to violate the credit ceilings as the earnings expected from their credit operations more than compensated the loss in the form of penalty. Banks also began to issue guarantees to their clients who could borrow funds from DFIs/NBFIs against their guarantees.

Not only did credit for budgetary support enjoy prior claim over all other credit allocations, very often the Government borrowed excessively from the banking system, resulting in monetary expansion exceeding the target agreed in the credit plan. During the five years ended June 1988, government borrowing from the banking system accounted for nearly $55 \%$ of increase in monetary assets, including $64.5 \%$ during $1987-88$.

\section{(XII) Monetary Policy, Economic Growth and Inflation During 1972-88}

This period witnessed a series of changes in economic management and policies including in particular financial polices. The Bhutto regime was marked with radical changes like widespread nationalization - industry, shipping, insurance, education, banks etc. - and hence the increasing role of the public sector in economic management. In the absence of both (i) trained cadres for the management of economic enterprises and (ii) accountability mechanism, together with intervention in economic affairs by party people and labor unions, as well as marginalization of the role of the private sector, economic growth was poor and inflation touched record high levels.

However, during the Bhutto regime sizeable public investment took place in mega Public Sector Projects. Thus, if during 1974-75 the budget deficit was $10.6 \%$ of the GDP, the public sector program was over $10.2 \%$ of the GDP. Economic benefits of these heavy investments were largely reaped by the Zia-ul-Haq regime. 
Economic growth during the Zia-ul-Haq period was quite impressive, partly attributable to the good performance of agriculture - in no small measure to availability of water and fertilizer - rehabilitation of private sector and the law and order situation. Also, there was no political intervention and economic management was essentially in the hands of experienced bureaucrats.

The table below shows economic growth, monetary expansion and changes in prices, during 1972-88.

Table-4: Inflationary Gap 1972-1988

\begin{tabular}{|c|c|c|c|c|}
\hline End June & $\begin{array}{l}\text { Consumer } \\
\text { Price Index } \\
\text { (CPI) }\end{array}$ & $\begin{array}{l}\text { Monetary } \\
\text { Growth }\end{array}$ & $\begin{array}{c}\text { GDP } \\
\text { Growth } \\
\text { (fc) }\end{array}$ & $\begin{array}{c}\text { Inflationary } \\
\text { Gap }\end{array}$ \\
\hline & (a) & (b) & (c) & (b-c) \\
\hline 1972 & 4.7 & 3.6 & 2.1 & 1.5 \\
\hline 1973 & 9.7 & 22.7 & 6.7 & 16.0 \\
\hline 1974 & 30.0 & 13.3 & 7.0 & 6.3 \\
\hline 1975 & 26.7 & 7.8 & 3.3 & 4.5 \\
\hline 1976 & 11.7 & 25.9 & 3.4 & 22.5 \\
\hline 1977 & 11.8 & 24.3 & 2.8 & 21.5 \\
\hline 1978 & 7.8 & 23.0 & 7.8 & 15.2 \\
\hline 1979 & 6.6 & 23.5 & 5.6 & 17.9 \\
\hline 1980 & 10.7 & 17.6 & 6.9 & 10.7 \\
\hline 1981 & 12.4 & 13.2 & 6.2 & 7.0 \\
\hline 1982 & 11.1 & 11.4 & 7.6 & 3.8 \\
\hline 1983 & 4.7 & 25.3 & 6.8 & 18.5 \\
\hline 1984 & 7.3 & 11.8 & 4.0 & 7.8 \\
\hline 1985 & 5.7 & 12.6 & 8.7 & 3.9 \\
\hline 1986 & 4.4 & 14.8 & 6.4 & 8.4 \\
\hline 1987 & 3.6 & 13.7 & 5.8 & 7.9 \\
\hline 1988 & 6.3 & 12.3 & 6.4 & 5.9 \\
\hline Average & 10.3 & 16.3 & 5.7 & 10.6 \\
\hline
\end{tabular}


Monetary Expansion, Economic Growth and Inflation 1972-1988

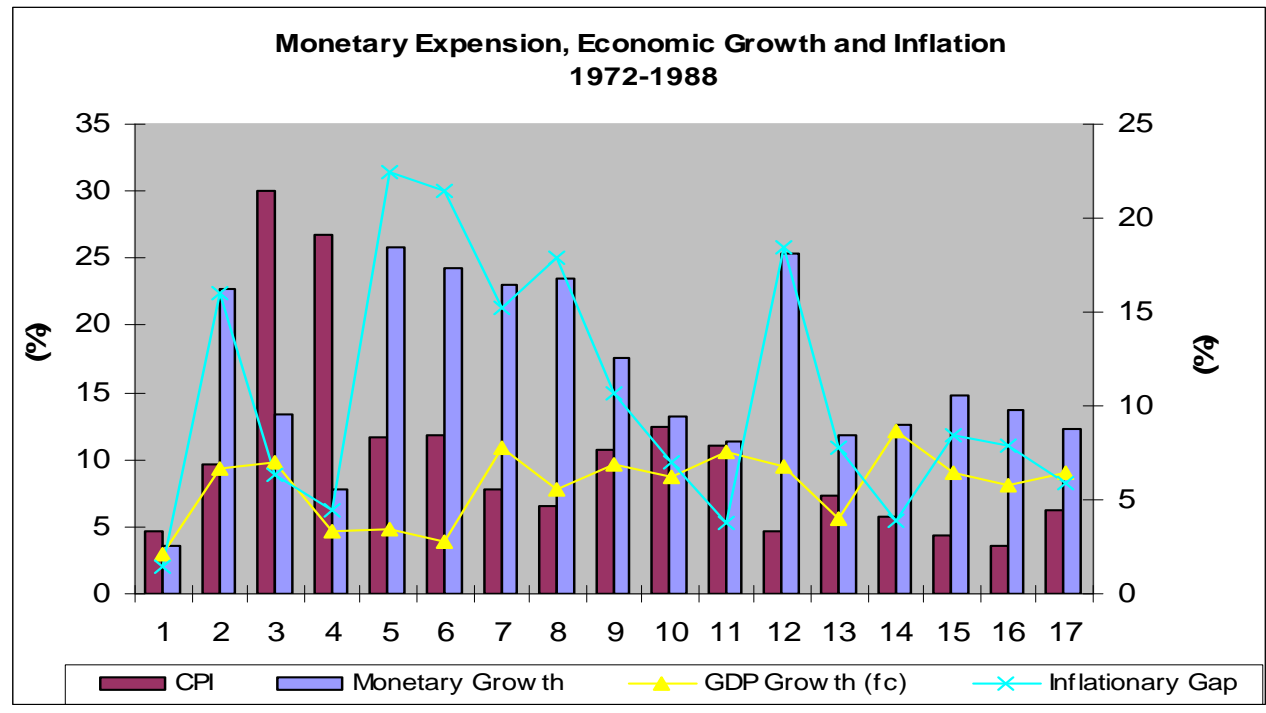

The table shows that (1) during 1973 and 1976 to 1979 annual monetary growth was over $20 \%$ and this is reflected in the increase in prices. (2) the average growth rate during the Bhutto regime was $4.6 \%$ with an average price increase of $18 \%$. Corresponding figures for the Zia-u1-Haq period were $6.6 \%$ and $7.3 \%$ respectively. Apart from the large fiscal deficit during the Bhutto regime (an average $8.4 \%$ of GDP) and heavy bank borrowing, quantum jump in the unit cost of imports contributed to inflation as a cost-push factor.

One thing that emerges from the Table is that during this period there is no monetary overhang; average growth rate of $5.7 \%$ over the years and $10.3 \%$ increase in prices give an average of $16 \%$ increase in money incomes. This compares with an average of $16.3 \%$ increase in monetary growth. This is despite the fact that during the Bhutto period cost push factors in the form of increases in the unit prices of imports together with the devaluation of the rupee in May 1972, were quite strong.

\section{(XIII) The Government, the State Bank and Monetary Policy}

Since the early 1970s, when banking reforms were introduced including institutional changes and subsequent nationalization of banks in 1974, the Government has exercised virtually decisive influence on the management of monetary policy. However, even before the changes, the rules provided an effective control of the Government in the use of instruments of monetary policy. More specifically, reserve requirements of the commercial banks as well as liquidity requirements, the two important instruments of monetary policy, could be changed only with the government's approval. 
Very frequently, the actual budget deficit was larger than the original estimates, mainly because of the Government's over-estimation of revenues and under-estimation of expenditure as well as because of unforeseen developments resulting in additional claims on Government resources. Borrowing from abroad depended on several imponderables, while non-bank borrowing, being on tap, varied considerably vis-à-vis budget estimates. An attraction for government borrowing from the banking system was the sizable subsidy involved. The State Bank was paid a nominal interest of $0.5 \%$ on ad hoc Treasury Bills while banks, over the years, got 4.5 to $6 \%$ on Treasury bills on tap. There was no limit on government borrowing from the banking system. All these features have meant erratic behavior of government's actual bank borrowing, both in terms of year to year changes in absolute amount as well as in terms of actual borrowing vis-à-vis original and revised estimates. Such changes have constituted an element of uncertainty and very often a leakage in the management of monetary policy.

It is noteworthy that for most of the period during 1976-88, for which detailed data are available, Government and Public Sector Enterprises used a great bulk of total bank credit. During 1975-76 government's bank borrowing for all purposes at Rs. 5.24 billion together with bank borrowing by Public Sector Enterprises of Rs. 1.76 billion constituted $80.57 \%$ of total credit expansion of Rs. 8.51 billion. This percentage stood at 79.5 in 1977-78. It showed a sharp decline to 41.7 in 1985-86 and further to 37.6 in 1986-87. For the rest of the years it varied between 56.7 in 1981-82 and 76.4 in 1979-80.

Table-5: Bank Borrowing

Rs. in billion

\begin{tabular}{rrrrr}
\hline & \multicolumn{2}{c}{ Government } & \multicolumn{2}{c}{ Non-Government } \\
\cline { 2 - 5 } & Target & Actual & Target & Actual \\
\hline Bhutto Regime 1972-73 - 1976-77 & 9.17 & 16.69 & 18.87 & 16.35 \\
Zia-ul-Haque Regime 1978-88 & 64.30 & 105.6 & 142.21 & 162.00 \\
\hline Total & $\mathbf{7 4 . 4 7}$ & $\mathbf{1 2 1 . 8 5}$ & $\mathbf{1 6 1 . 0 8}$ & $\mathbf{1 7 8 . 3 5}$ \\
\hline
\end{tabular}

Table-6: Government Bank Borrowing for Budgetary Support \& Commodity Operations (1972-73 -1987-88)

Rs. in billion

\begin{tabular}{lrr}
\hline & \multicolumn{1}{l}{ Target } & \multicolumn{1}{c}{ Actual } \\
\hline Budgetary Support & 43.06 & 104.30 \\
Commodity Operations & 14.40 & 21.60 \\
\hline
\end{tabular}




\section{(XIV) Quasi Fiscal Deficit}

Apart from borrowing from the banking system for budgeting support, the banking system - both the State Bank and Scheduled banks provided resources to Government, both Central and Provincial, to PSEs, as well as resources and subsidy to government sponsored institutions. This is a quasi-fiscal deficit, which may comprise the following.

i. Government's bank borrowing for (stood at Rs. 11.46 billion as of commodity operations end June 1988)

ii. Bank loans to PSEs (stood at end June 1988- 36.12 billion)

iii. State Bank lending to development (outstanding as of end June banks and other institutions 1988 Rs. 34.1 billion)

iv. Subsidy involved:

a) Lending to DFIs / NBFIs Rs. 3.7 billion during 1988

b) Subsidy on Lending to government During 1973-88 Rs. 9.43 billion

\section{(XV) Market Based Monetary Management: Reserve Money Programming}

Before the introduction of financial sector reforms State Bank had adopted monetarist approach to monetary policy. Monetary expansion and credit requirement of the economy were worked out on the basis of (i) targeted growth rate (ii) inflation target and (iii) the likely behavior of the foreign sector. Allocation of credit was through administrative fiat: credit ceilings, credit deposits ratio and several schemes of directed, mandatory and concerning credit. The process of shifting monetary policy to indirect, market-based instruments went roughly through four phases. Within the overall framework of the Annual Credit Plan, the elaborate regime of credit ceilings introduced in October, 1973 for individual banks to meet the credit needs of the private sector, and later on of PSEs also, continued till end-June, 1992, although by this time a number of reform measures had already been taken to initiate the transition from administrative fiat to a market-oriented approach. The system of credit ceilings was replaced with the somewhat flexible system of credit deposit ratio $(\mathrm{CDR})^{1}$ with effect from $1^{\text {st }}$ of August, 1992. Various reforms continued during this phase (1992-93 to 1994-95), culminating in the

${ }^{1}$ The decision to discontinue the scheme of credit ceilings was made on $14^{\text {th }}$ January, 1992 to be effective from $1^{\text {st }}$ July, 1992. The credit- deposit ratio as an instrument of credit management became effective from $1^{\text {st }}$ August, 1992. 
abolition of CDR itself on $30^{\text {th }}$ September, 1995. This marked the beginning of the third phase covering the period up to June 2001. Indicative credit targets replaced the $\mathrm{CDR}$ and the main reliance to conduct monetary policy was placed on Open Market Operations $(\mathrm{OMOs})^{2}$. Subsequently, when the Pak rupee was put on free float in May 1999 and in the real sense in July, $2000^{3}$, Monetary Policy and Exchange Rate Policy were fully integrated. This marked the beginning of the fourth and the final stage.

Market based monetary management involved reserve money programing, the broad objective of which was to develop a framework to project the desired path for reserve money, which was consistent with the targeted growth in money $\left(\mathrm{M}_{2}\right)$ derived from the macro-economic framework. The reserve money is affected by (a) deposit mobilization, (b) government cash position, (c) government borrowing requirements, (d) maturity of existing government debt, (e) reserve requirements and (f) borrowings from the State Bank. The State Bank has to watch all these variables and attempt forecasts in order to arrive at a judgment on the level of reserve money that is consistent with the target of monetary expansion. All this is done within the framework of the Annual Credit Plan.

\section{(XVI) Monetary Policy, Prices and Economic Growth 1988-89 - 1998-99}

This period is one of transition of monetary policy management from Credit Ceilings (upto end June 1992), Credit Deposit Ratio (August 1992 September 1995) and indicative targets (October 1995 - Jan. 2001) to reliance of monetary policy on OMOs. Also, this is a period of political turmoil and substantive policy changes. Political regimes during this period were more pre-occupied with survival than with medium or long-term economic policies. A number of interim/caretaker governments undertook important economic and financial sector reforms, especially during the Wasim Sajjad-Moinudin Qureshi and Farooq Leghari-Malik Meraj Khalid terms. Politically elected leadership found it difficult to implement Fund/Bank conditionalities for fear of losing popular support. As a result, in terms of growth, the 1990 s was described by some analysts as a 'lost decade'

\footnotetext{
2 The State Bank had started OMOs on ad hoc basis in October 1991, and upto September 1995 were conducted on a very restricted basis. SBP sold Treasury bills from its portfolio in the case of surplus liquidity in the market.

${ }^{3}$ In the real sense 'in July, 2000' because although Pakistan declared free float in may 1999, it did not observe the basics during 1999-2000 as there was no IMF program in place and authorities took steps to stabilize the rupee as they wished. (cf. SBP Annual Report: 2000-2001 pp. 152, 154).
} 
for Pakistan ${ }^{4}$, partly because of reforms, punctuated by lapses, which included demand management in the context of prevailing high inflation rates and large fiscal deficits. Growth in per capita income dropped to slightly over 1 percent. In the view of some others, structural and other reforms, with whatever speed implemented, made possible the turnaround of the economy by the close of the $1990 \mathrm{~s}^{5}$.

In the 1990s the growth rate tumbled largely because of decline in capital inflows and a number of other factors ${ }^{6}$ including persistent lapses in implementation of structural reforms and stabilization measures. Thus in terms of economic growth, the period came to be known as the 'lost decade'.

The worsening law and order situation during the 1990s affected not only the security of life, property and honor of individuals, but it also created difficulties in entering into contracts and their enforcement. In the wake of internal instability and judicial lacunas, investors, both domestic and foreign, could not exploit investment opportunities in the country. Rampant corruption and worsening standards of governance of almost all national institutions amounted to a prohibitive cost of doing business in the country.

Pakistan's credibility was also on the decline externally in general, but particularly among the International Financial Institutions and also domestically with the general public. Agreements signed by successive governments with the IMF and the World Bank were breached more often than implemented. Tough decisions to end subsidies, to remove price distortions, mobilize domestic resources, widen the tax base, eliminate discretionary controls, were avoided with the result that the cumulative impact of these deferred decisions eroded the productive base of the economy and created a large credibility gap vis-à-vis the International Financial Institutions ${ }^{7}$.

Withdrawals from foreign currency deposits of resident Pakistanis were suspended in May, 1998. This antagonized an important class of investors ${ }^{8}$.

\footnotetext{
${ }^{4}$ Dr. Ishrat Hussain, 'Economic Challenges Facing Pakistan' Lecture delivered at the Centre for Development \& Democracy, Karachi on $19^{\text {th }}$ January, 2001.

${ }^{5}$ Sartaj Aziz, 'Was the 1990s a 'lost decade'?' Dawn, Feb. 11, 2001.

${ }^{6}$ Rashid Amjad (Director, Policy Planning, International Labour Organization (ILO), Geneva), ‘Solving Pakistan’s Poverty Puzzle: Who Should We Believe? What Should We Do?’, PIDE, January 2004.

${ }^{7}$ ibid

${ }^{8}$ Dr. Ishrat Hussain: 'Economic Challenges Facing Pakistan' Lecture delivered at the Centre for Development \& Democracy, Karachi on $19^{\text {th }}$ January, 2001 in 'Leading Issues Facing Pakistan Economy’ - March 2000-February 2003.
} 
In my view the 1990s was not the "lost decade". In fact despite a high rate of economic growth, the 1980s was a period of missed opportunities, and the legacy the economic managers of this period left for those who followed was not an enviable one. First was the rising fiscal deficit, the result of a very large increase in government expenditure (including defense), which left a crushing debt burden on the economy. Second, if the needed economic reforms to achieve macro balance and competitiveness had been initiated when the economy was in a relatively strong position it would have lessened the burden on the economy and the people of undertaking these reforms when the economy was in a relatively much weaker position.

Juxtaposed to a difficult and trying economic environment, the 1990s saw a slowing down of economic growth because of shocks beyond the control of economic managers. There had been large fluctuations and a decline in cotton production which was persistently hit by pest attacks, continuing slowing down of remittance inflows, bad weather conditions which directly affected agricultural production and economic sanctions after Pakistan's nuclear explosion in May 1998. Frequent changes in governments in this period added to economic uncertainty and discontinuity in economic decision-making.

Superimposed over these negatively contributing growth factors were the shortcomings of economic management in the 1990s, which made matters worse. The foremost among them was the sequencing and pace of implementation of the economic reforms program.

Table-7: Macroeconomic Indicators: Actual (\% Growth)

\begin{tabular}{crrcc}
\hline Year & GDP & Inflation & Monetary Assets & Inflationary Gap \\
\hline $1988-89$ & 6.7 & 10.4 & 7.8 & 1.1 \\
$1989-90$ & 7.0 & 6.0 & 17.5 & 10.5 \\
$1990-91$ & 3.9 & 12.7 & 17.4 & 13.5 \\
$1991-92$ & 3.4 & 10.6 & 26.2 & 22.8 \\
$1992-93$ & 2.8 & 9.8 & 17.8 & 15.0 \\
$1993-94$ & 4.5 & 11.3 & 18.1 & 13.6 \\
$1994-95$ & 5.3 & 13.0 & 17.2 & 11.9 \\
$1995-96$ & 4.6 & 10.8 & 13.8 & 9.2 \\
$1996-97$ & 1.9 & 11.8 & 12.2 & 10.3 \\
$1997-98$ & 3.5 & 7.8 & 14.5 & 11.0 \\
$1998-99$ & 4.2 & 5.7 & 6.2 & 2.0 \\
Average & 4.3 & 10.0 & 15.3 & 11 \\
\hline
\end{tabular}




\section{Monetary Policy, Inflation and Economic Growth (1999/00 to date)}

This period has witnessed rapid changes in a number of areas which posed formidable challenges to the economic managers in the country. In fact, this period has tested the technical acumen of the country's financial managers. In this part of the article these developments as well as the implications of policy responses are dealt with.

\section{(XVII) Economic growth}

There is visible optimism in the Pakistan economy: 6.4\% economic growth during 2003, 8.4\% growth rate during 2004-05 and $7.8 \%$ projected for the next few years. The growth rate during 2003-04 was driven by expansion in large scale manufacturing (LSM) in the areas of food, beverages, tobacco, automobiles, electronics, chemicals and fertilizer. During 2004-05 almost all the sectors contributed to the growth: Agriculture (7.5\%) Large Scale Manufacturing (12.5\%) and Services (7.9\%).

For the last few years the State Bank continued to pursue a growth accommodating policy stance. Consumer demand materialized as a result of record level of bank lending to the private sector and consequent availability of purchasing power. This was the growth engine which the government used. It was also expected that investments in a number of industries in LSM would create additional capacity, so that full utilization of existing capacity does not become a constraint.

All these developments originated in the foreign sector- building up of foreign exchange reserves entailing inflow of remittances and reverse capital movements. There were no investment opportunities to absorb the inflow of capital which resulted in a sharp decline in the interest rate. This liquidity found its way to real estate, the stock exchange and liberal lending by banks. These developments and issues stemming therefrom are discussed under the following headings:

1. Monetary and Credit developments

2. Interest rate policy

3. Inflationary pressures

4. Political back drop of these developments

5. Conclusion

6. Future outlook 


\section{(XVIII) Monetary and Credit developments}

The increase in liquidity in recent years has been immense as shown in the table below:

\section{Table-1: Causative Factors for Monetary Growth}

CP1 CP2

\begin{tabular}{lccccccccccccc}
\hline \multicolumn{1}{c}{ Rs. Bin } & FY96 FY97 FY98 & FY99 & FY00 & FY01 & FY02 & FY03 & FY04 FY05* FY05 FY05 \\
\hline Government Sector & 68.5 & 80.9 & 55.9 & -74.8 & 78.2 & -46.7 & 22.2 & -78.4 & 58.1 & 13.5 & 47 & 65 \\
- Net Budgetary Borrowing & 51.7 & 72.5 & 48.0 & -75.2 & 40.0 & -32.3 & 14.3 & -56.0 & 63.7 & 16.3 & 45 & 60 \\
- Commercial banks & na & na & na & na & -95.1 & -0.8 & & 193.3 & 3.7 & & & \\
- Central Bank & na & na & na & na & 135.0 & -31.6 & -249.2 & 60.0 & 143.0 & & \\
- Commodity Operations & 5.9 & 5.7 & 10.6 & 3.6 & 40.1 & -12.5 & 5.3 & -26.6 & -8.2 & -5.1 & 5 & 5 \\
- Zakat, Privatization etc. & 10.9 & 2.8 & -2.7 & -3.3 & -1.8 & -1.9 & 2.5 & 4.2 & 2.6 & 2.3 & -8 & 0 \\
Non-Government Sector & 63.4 & 61.9 & 84.2 & 119.2 & 26.0 & 69.2 & 19.0 & 148.5 & 315.4 & 331.3 & 190 & 330 \\
- Credit to Private Sector & 54.8 & 61.1 & 76.3 & 84.1 & 18.1 & 56.4 & 53.0 & 167.7325 .2 & 348.7 & 200 & 350 \\
- (growth rate\%) & 17.3 & 15.9 & 17.0 & 14.2 & 2.9 & 8.1 & 6.6 & 18.6 & 34.3 & 27.4 & 15.7 & 27.5 \\
- Credit to PSEs & 6.1 & 2.0 & 8.6 & 16.2 & 7.6 & 20.6 & -19.5 & -11.6 & -2.9 & -11.4 & -5 & -15 \\
- SBP Credit to NBFIs & 2.5 & -1.2 & -0.7 & 18.9 & 0.4 & -7.7 & -14.5 & -7.6 & -6.9 & -6.1 & -5 & -5 \\
Other Items Net & 21.1 & 5.2 & 26.8 & 0.3 & 14.5 & 30.9 & -12.0 & -61.7 & -9.2 & -88.9 & 11 & 65 \\
Domestic Credit Expansion & 152.9 & 147.8 & 167.0 & 44.7 & 118.7 & 53.4 & 29.2 & 8.5 & 364.3 & 255.8 & 30 & 30 \\
Monetary Expansion & 113.9 & 114.6153 .1 & 74.2 & 120.1 & 126.0 & 235.3 & 317.4 & 407.9326 .6 & 280 & 360 \\
(\% charge) & 13.8 & 12.2 & 14.5 & 6.2 & 9.4 & 9.0 & 15.4 & 18.0 & 19.6 & 13.1 & 11.5 & 14.5 \\
\hline Real growth (\%) & 6.6 & 1.7 & 3.5 & 4.2 & 3.9 & 1.8 & 3.1 & 5.1 & 6.4 & 6.6 & 7.0 \\
Inflation (annual avg CPI) & 10.8 & 11.8 & 7.8 & 5.7 & 3.6 & 4.4 & 3.5 & 3.1 & 4.6 & 5.0 & 7.0 \\
M2 over nominal growth & -3.6 & -1.3 & 3.2 & -3.7 & 1.9 & 2.8 & 8.8 & 9.8 & 8.6 & & \\
\hline
\end{tabular}

Source: Annual Report FY 03 \& Statistical Bulletin August 2004, SBP* July to April 9, 2005.

As can be seen from the Table above the rate of monetary expansion picked up from FY02 and since then total monetary expansion has been Rs. 1371.9 billion (upto $25^{\text {th }}$ June 2005) and amounted to $90 \%$ increase over the stock of money in 2000-01. Credit expansion amounted to Rs. 371.2 billion between $1^{\text {st }}$ July 2004 and $25^{\text {th }}$ June, 2005. Private sector credit expanded by Rs. 390.3 billion between $1^{\text {st }}$ July 2003 and $25^{\text {th }}$ June, 2005.

Once liquidity is injected into the system it becomes purchasing power in the hands of economic agents. This purchasing power keeps changing hands. Thus, as a monetarist would say, the excess purchasing 
power does not guarantee sustained increase in aggregate output. A short term increase in production will be accompanied by rising prices. Hence the view that money is neutral and inflation is a monetary phenomenon. There is always a time lag between the injection of liquidity and its manifestation as inflation". The latest research shows that this time lag is between 18 to 20 months. This aspect of monetary policy has not received any attention in the State Bank of Pakistan. Lately, the State Bank has acknowledged the market realities and has started jacking up the interest rates including the discount rate. However, it still seems reluctant to increase interest rates to match inflation. Average lending rate in May 2005 was 7.97 while the rate of income in prices is considerably above $8 \%$. There would not have been any such problem had the State Bank not allowed a sharp slide in the interest rate in the first place. It appears that emphasis is clearly on growth and the State Bank compromised its primary objective of maintaining price stability.

Also, the recent increase in prices was nowhere in the calculation of the State Bank. The Bank has been changing the expected rate of inflation during the current year after every few months. This clearly shows that the State Bank had not done its homework. When increase in prices turned out to be beyond the State Bank's expectation, it had no alternative to tightening the monetary policy. In its second quarterly report the Bank acknowledged that the token tightening of monetary policy did not have any impact on demand for credit by the private sector which upto $2^{\text {nd }}$ April 2005 amounted to Rs.362 billion, compared with original estimates of Rs.200 billion and revised estimates of Rs.350 billion for the year as a whole.

In fact despite increase in the interest rate, though still negative in real terms, the private sector continued to borrow from the banking system. As of $25^{\text {th }}$ June 2005 credit in the private sector stood at Rs. 390.3 billion. The stock market bailout by banks entails a further increase in the private sector credit over and above normal lending. Full year bank lending to the private sector may very well be around Rs. 400 billion.

The monetary overhang between FY01 and FY04 was 30\%. Even calculated from FY96, the monetary overhang by end of FY04 was 26.5. As can be seen from the last row in Table- 1 the FY05 has absorbed only $1.2 \%$ of this overhang. The rest of the overhang, though not entirely stemming from credit expansion, will manifest itself sooner or later.

\section{(XIX) Interest Rate Policy}

\footnotetext{
${ }^{9}$ In the case of Pakistan the length of lag has been calculated by Prof. Anjum Nasim of LUMS in his monograph on "Determinants of Inflation in Pakistan" and by Manzoor Hussain of State Bank of Pakistan.
} 
It was as late as $11^{\text {th }}$ April 2005 that the State Bank was awakened to the need for adjustment in the interest rate to tighten the liquidity in the economy. Reluctance on the part of the State Bank to raise the interest rates close to the rate of inflation has been a major failure of the Bank. The State Bank hesitated for a long time to tighten monetary policy which could be attributed to the Bank's (and government's) perception that cheap credit is one of the main reasons for strong growth. Since August 2003 market interest rates became increasingly negative in real terms. This failure, in the context of excess of liquidity in the economy, gave rise to many problems. This is despite the fact that the State Bank's attention was drawn- more than once and by more than one entity - to the urgent need to adjust the interest rate. More specifically, with the inflow of money in the form of Net Foreign Assets (NFA), the State Bank was unable to stop the slide in the interest rate. An attempt was made to absorb the excess liquidity through the auctioning of public debt. This was not an effective method of sterilization and the interest rate declined to a record low level. This decline in the interest rate was of tremendous advantage to the corporate sector and to the government in more than one way.

It needs to be mentioned that auctioning of public debt is not the conventional way of sterilization. Recently, a number of countries, faced with similar situations, sterilized capital inflows through OMOs, window guidance (direct control on the credit volume of selected banks) and / or increased Reserve Requirements. Sterilization of excess liquidity through these methods resulted in checking the slide in the interest rate. It was observed that where lending rate did not fall in nominal terms at the time of change in the Reserve Requirements, inflation was also declining. However, in the case of Pakistan the State Bank deliberately kept the interest rate low to encourage credit expansion presumably to patronize the growth rate, to the complete exclusion of any consideration for price stability, which is the primary function of a Central Bank.

The State Bank could have prudently controlled liquidity by using inflow of capital to retire expensive foreign debt. But the State Bank did not formulate a policy in this regard. The Bank should have planned prepayment much earlier. The Bank did it; but it was too late and too little. Also, the State Bank allowed the government to borrow an unlimited amount from banks at a low rate of interest. The Government, in order to keep low interest rate on its debt instruments, borrowed heavily from the State Bank to finance its maturing loans from commercial banks which would not rollover the government debt at low interest rate. Thus as of $25^{\text {th }}$ June 2005 , governments net budgetary borrowing at Rs. 68.78 billion was the result of government borrowing of Rs. 154.55 billion from the State Bank and retiring their debt with the scheduled banks to the amount of Rs. 
85.77. In the process of maintaining a low rate of interest, the SBP allowed increase in liquidity on two counts: gave additional resources to commercial banks and added to reserve money which is the base of monetary expansion. It is not clear whether this was a deliberate policy of the State Bank or was manipulated by the Finance Division. All the same, it is a fact that the State Bank compromised in every possible way to keep the interest rate at an unsustainably low level.

Therefore, the Government benefited greatly from the low interest rate environment, as it was able to reduce substantially its cost of funding from both the bank and non-bank sources. The reduction in cost of borrowing helped reduce the future debt servicing cost and created a fiscal space for the initiation of development programs. The government was able to make pre-payments of expensive external debt amounting to US\$ 1.17 billion during FY04 (the Government should have done more).

The low cost funds available to the corporate sector enabled many companies to strengthen their balance sheets, improved profitability and invest retained earnings along with bank borrowing for expansion, modernization or enhance capacity utilization. Due to availability of cheaper bank financing, corporate issuance of TFCs had declined in the preceding two years. Banks moved into new areas of business such as housing, SMEs, consumer durables and agriculture. Thus, higher demand for funds by the private sector and increased public sector development spending helped meet the postulated targets of the domestic economy.

At one time it was feared that the State Bank could run out of stock of treasury bills. It is difficult to visualize what would be the reaction of the State Bank under such circumstances. The advisable course for the State Bank was to absorb excess liquidity through Open Market Operations (OMOs) and not allow the sharp decline in the interest rate. Also, the State Bank could have issued its own paper to pick up excess liquidity in which case the State Bank could be more aggressive and determine the level of interest rate in accordance with the macroeconomic fundamentals ${ }^{10}$.

\footnotetext{
${ }^{10}$ Reportedly the option was not resorted to, one reason being that the rules governing the operations of the State Bank do not allow this. It appears that the State Bank is always caught off-guard whenever there is an unanticipated emergency. Precisely the same thing happened when there were scandals of Finance Companies in 1979 and again in 1987-88. By the time the State Bank got the requisite powers and started inspection etc. operators of Finance companies had made away with peoples' money. Laws can always be introduced on an emergency basis if one is clear about the urgency of the objective.
} 
However, it appears that the State Bank had decided in favor of cheap credit which could benefit the Government, the banks and the corporate sector.

\section{(XX) State Bank's Present Stance}

The April $11^{\text {th }}$ hike in the discount rate was a long awaited step in the right direction. For the first time, the Governor of the central bank had talked about the need to ease the rapid pace of private sector credit expansion. Although this pace had been excessive for over two years, it is better late than never to take corrective steps.

Also the impressive sweep of the April $13^{\text {th }}$ T-bill primary auction in which the State Bank accepted all the bids on offer and pushed up the rates was sufficient. The end in view was to reduce inflation. Hence, the immediate focus of the central bank should be to reduce the pace of credit expansion. The government may not like this to undermine economic growth. Hopefully SBP will not be deterred by such external compulsions, and proceed with its duty to enforce monetary control.

The market feedback about the discount rate hike has been mixed. Some claim this will hit corporate profitability; undermine export competitiveness; reduce demand for credit (both consumer and corporate); increase the fiscal deficit; and slow growth. However, others claim that since inflation is still higher than revised lending rates, this will not have much of an impact on the economy. Car assemblers and manufacturers of consumer durables seem to echo the views of bankers that this adjustment may not be able to make a dent on the pace of credit expansion. Even the Ministry of Finance is of the view that this increase in interest rates will not impact aggregate growth (in other words, the credit that has been driving growth is likely to remain in place).

To formulate an outlook, the following factors are important:

1. In terms of overall M2 growth, the bumper wheat crop and the enhanced support price has resulted in a credit expansion of Rs. 21.82 both (June 25, 2005) for commodity operations compared with a retirement of Rs. 8.62 billion during the same period last year.

2. The bailout package for the stock market entails funding from banks, has contributed to credit expansion to the private sector, which, as of $25^{\text {th }}$ June 2005 stands at Rs. 390.3 billion and is likely to be around Rs. 400 billion by $30^{\text {th }}$ June, 2005 . 
To reduce credit expansion banks will have to stop discretionary loans. The market-based avenue to do this is to incentivize banks not to lend. This can either be done by enticing banks into government securities, or by draining away available liquidity. To entice banks into securities, returns would have to be jacked up sufficiently, so that on a risk-reward trade-off, banks would rather lend to the government than to the private sector. This will require a substantial increase in the rate and supply of PIBs, so that private sector assets cannot compete. With inflation close to double digits, the quantum increase in market rates is likely to be very large.

In terms of draining liquidity, either SBP rethinks its OMOs and ensures that bank liquidity remains tight or cash reserve requirements (CRR) should be increased. A one percent increase in CRR will absorb Rs. 22.5 billion, which means CRR would have to be increased by 2 or 3 percent to be meaningful. However, CRR is a very blunt instrument, which harks back to the days of direct monetary policy. Its use in a non-emergency situation shows that SBP is unable to use interest rates for monetary control.

A far superior option is to increase liquid asset requirements. At present, this is 20 percent of demand and time liabilities (DTL): CRR is 5 percent and T-bill/PIB holdings are 15 percent. The best option SBP has is to increase liquid assets to 25 percent, with the requirement that only $\mathrm{T}$ bills should be eligible. Increasing SLR is a signal of monetary tightening, but is not as brutal and inefficient as increasing CRR.

Increasing SLR, provided banks are not holding excess securities, would strengthen the balance sheet of banks by forcing them to hold government securities instead of private sector assets. There is little doubt that this drying up of private sector credit will hurt and attract negative press. However, in this euphoria of high growth, someone has to step on the brakes, otherwise the banking system is heading towards trouble - the only question is, how systemic the problem is and how many banks go under.

SBP is unable to bring down inflation in the next few months. However, it must show real intent - that it is taking tough steps to reduce the expansion of private credit irrespective of the pain it will cause. Only this will determine whether the central bank is serious about its main responsibility - price stability.

\section{(XXI) Inflationary Pressures}

In its monetary policy statement in July 2003 the State Bank said that inflation should not be the only policy objective in countries like ours 
and the Central Bank rather should pursue balanced policy, ensuring growth promotion coupled with containment of inflation, since employment generation was possible only through high growth to improve the welfare of people. Yet in practice the State Bank has clearly compromised its policy objective of maintaining price stability. The Bank has patronized growth at the expense of price stability. The cumulative monetary overhang of $26.5 \%$, as of end June 2005 will manifest itself sooner or later.

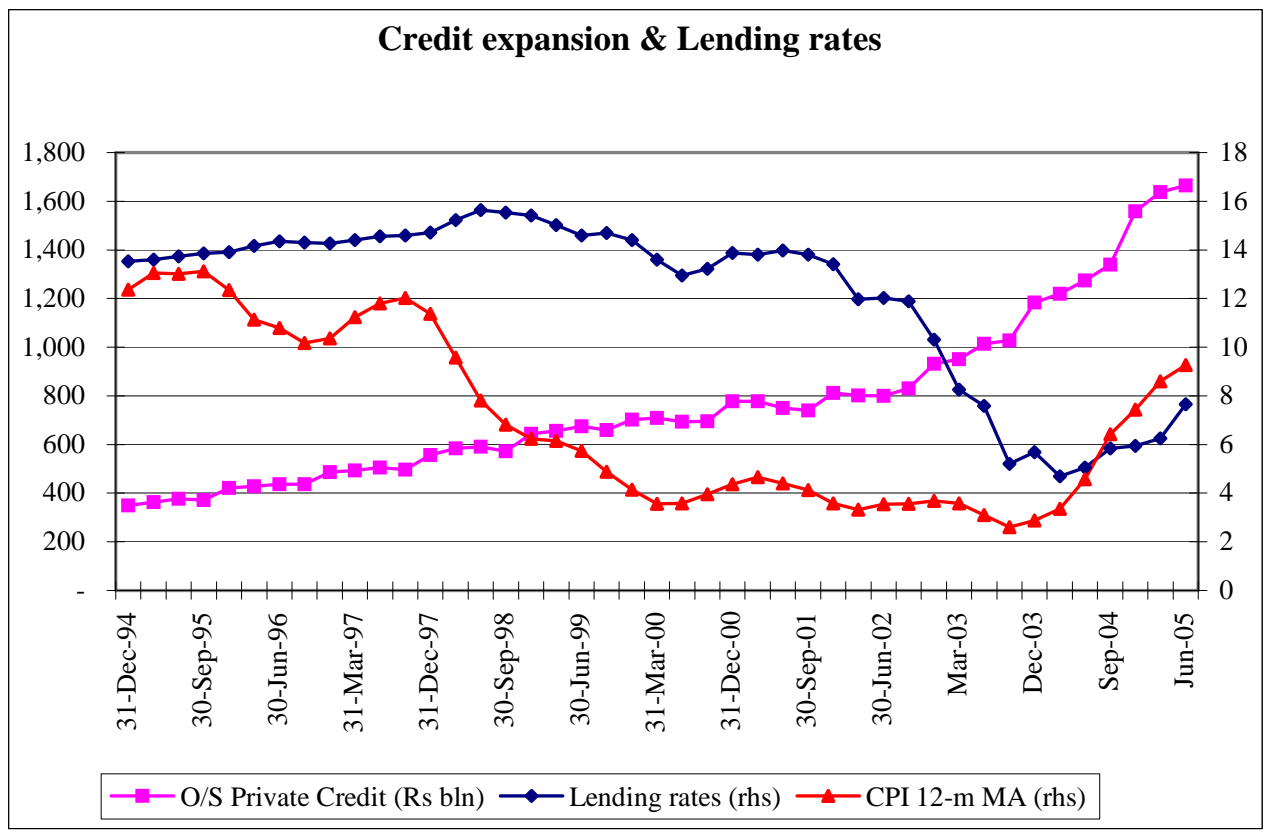

Despite a massive monetary expansion of 19.6\% during FY04 the increase in Consumer Price Index (CPI) remained low at $4.6 \%$. The fact is that at the macro level, the sharp increase in money supply has not had an immediate inflationary impact for two reasons: one, there is always a time lag between the injection of surplus liquidity and its impact on prices; and two, since this funding was generated by the accumulation of foreign assets, the inflationary impact was further delayed and was less direct. The impact is still pending. Although the recent increase in price is to an extent costpush factors (e.g. basic food items, which constitute 40 percent of the basket), the monetary overhang continues to impact the Consumer Price Index (CPI). The recent increase in CPI has been driven by food items and the house rent index. Food prices have increased because of the government's unsuccessful effort to increase the supply of key items (wheat, sugar, etc), while the house rent index is computed on a basket of construction inputs. Government's unsuccessful efforts to contain inflation and SBP's measured tightening of monetary policy, has not given much 
comfort to the market. The injection of liquidity in the past three years has not been a part of an ambitious development agenda, but resulted from reverse capital flows and excessive borrowing from the banking sector. This means the liquidity is largely controlled by the economic elite, which implies purchasing power still remains with the rich. Over time, however, this purchasing power will filter down to the working class, which will eventually begin to impact the prices of basic goods and services (demand pul1).

As stated earlier, three intra year adjustments in the target rate of increase in prices signal that the State Bank does not have a proper handle on monetary policy. Inflation during $2004-5$ is close to double digit compared with the original target of $5 \%$. In its assessment of actual inflation, the State Bank has virtually completely ignored the time lag between monetary expansion and its impact on prices. Also, the recent tightening of monetary policy through increase in interest rates shows that:

a) to be effective in developing countries like Pakistan, changes in doses of policies would have to be rather large for various reasons

b) for the corporate sector, it is the availability of credit more than the level of interest rate which is more significant .

Therefore, the State Bank has to rectify its stance of accommodative monetary policy.

The State Bank admits in its second quarterly report 2004/05, that a sharp increase in inflation has reduced the competitiveness of the export sector. However, the State Bank is not clear in its interpretation of monetary management when it says, "the regime of relatively cheap credit is contingent on fiscal discipline and pro-growth policies”.

The State Bank has not come around to accept that the current inflationary pressures are largely the result of a loose monetary policy. The State Bank continues to believe that easy monetary policy is just one of the factors and that cost push factors like increase in the prices of food and oil are causing inflation. The State Bank conveniently forgets that the cheap credit policy added to effective demand in a big way; that the stock of bank credit to private sector jumped from Rs. 800.46 billion at the end of June 2002 to Rs. 1664.56 billion as of $25^{\text {th }}$ June, 2005 , an increase of about $108 \%$ in three years. Earlier, bank credit to the private sector had increased by $112.9 \%$ in seven years from end June 1995 to end June 2002. Also credit deposit ratio rose from 54.9 as of end December 2002 to 68.9 as of $25^{\text {th }}$ June, 2005. 
The third quarterly report of the State Bank on the state of Pakistan economy admits that the policy of "easy money" contributed to inflation but does not say that this is the most important factor. The Report states,

"The impact of rise in aggregate demand due to easy monetary policy would be effectively curtailed through tightening of monetary policy, however, following fiscal and administrative measures are required to ease the inflationary pressures emerged due to supply shocks": the report further says, "the hoarders should be dealt with according to the regulations. It has been observed that the abnormal profit margins at retail levels are prevailing in the case of vegetables and fruits. Formation of effective consumer associations may monitor these margins and advise the consumers about the appropriate prices of these items, or to avoid consumption of some item, if price is unreasonably high. Alternatively, responsibilities of the existing price control committees may be extended". The bottom line is all the more imaginative "Since price setting is all about the price elasticity of demand, consumer may show resistance though collective actions".

The report suggests eight fiscal measures to contain inflationary pressures. With these recommendations, the State Bank is passing on the buck to the government and the people of the country. However, a timely action by the State Bank to tighten monetary policy would have obviated the need for such an advice.

\section{(XXII) Are There Price Bubbles in the economy?}

Theoretically, price bubbles (of assets) are created where there is (i) price inelastic demand and (ii) ample liquidity. Price inelastic demand means that supply will not increase in response to demand and excess demand is met by sufficient liquidity in the system. Fragmentary evidence suggests that the sharp increase in prices are concentrated in elite residential areas in three cities and as far as the stock exchange is concerned the activity appears to be concentrated in a handful of scrips. Thus, fixed supply and ample liquidity have given rise to increase in the price of assets.

\section{(XXIII) Political Considerations}

The signal from Islamabad was clear: the government wanted stronger growth and wanted this to be spearheaded by cheap credit. With a growth program firmly in place, the country's economic performance has developed a strong political dimension. The momentum for economic growth has been ascribed by the government to the following three factors: (1) the improvement in macroeconomic fundamentals; (2) an intangible "feel 
good" factor; and (3) bank credit at affordable rates. There is no denying the first and last, but the "feel good" factor itself is a direct result of easy credit. With market concerns about interest rates, this has created a degree of ambivalence to changing market conditions witnessed since the beginning of 2004.

There is an increasing pressure on market interest rates, as inflation has picked up quite sharply. There is also an implicit assumption that increasing T-bill and PIB rates will undermine the high growth projected for this year. At the very least, the authorities would want to ensure that the increase in market rates is not so sharp that banks have less free liquidity and start pricing up loans to the private sector. Since the government wants to maintain the growth momentum, it will want to ensure a smooth flow of consumer financing.

\section{Conclusion}

What has been happening in Pakistan's banking system is the classic case of using an easy monetary policy to jump start economic growth. There was a sharp acceleration in private sector credit following the SBP's decision to stop supporting market interest rates in November 2002; this followed the equally sharp fall in lending rates as banks desperately deployed liquidity. To ensure strong aggregate demand, retail petroleum prices and electricity rates were kept low. The resulting subsidy bill was effectively the government's first line of defense to ensure that inflation does not rise further. ${ }^{11}$ As the subsidies remained in place, the fiscal cost continued to rise. With recent adjustment in the petroleum prices the burden has partly been shifted to the consumer with clear implications for price increase.

The financial system is basically a closed circuit where funds flow from one agent / institution to another. If surplus liquidity is injected beyond the nominal growth of the economy, a monetary overhang is created. Despite the distinction between core and non-core, inflation is inevitable, even if it has not been fully captured by inflation indices. Unless the excess liquidity is absorbed, or its future growth is brought down, inflationary pressures will remain and spread.

To ensure a soft landing, the State Bank should continue to tighten monetary policy. The balance of payments deficit-including a record trade deficit of over $\$ 6.00$ billion during 2004-05 will also absorb some liquidity.

\footnotetext{
${ }^{11}$ This effort to contain inflation simply postponed the issue and increased the magnitude of the problem.
} 
The State Bank should not compromise on holding the price line. Before $11^{\text {th }}$ April 2005, there was the general impression that there was no Central Bank in the country and there was no monetary policy. The State Bank has to improve its image.

Sustainable economic growth requires more than cheap credit. It needs macro stability; a sustainable source of long-term funding; proper debt management; and a pool of educated (and healthy) workers who can be trained to compete. The latter is unlikely to be realized by trickle-down economics, which means a result oriented focus on social development is needed. The perceptible loss of price stability and the vulnerability of the banking system are fundamental issues that need to be addressed if the country is to sustain high economic growth.

An unbiased assessment shows that in the past three years or so the SBP's objectives were as clear as they were misplaced. The central bank was more interested in growth and justified rising inflation as the cost of higher growth. By prioritizing the government's growth objective, SBP had effectively downgraded its responsibility to maintain price stability. Furthermore, the fact that the State Bank expressed concern about asset bubbles, without taking responsibility for the liquidity that created bubbles, is misleading.

The on-going stock market crisis and the decision to get banks involved in a bailout, is an ominous sign. With banks already over-exposed in an environment of rising interest rates, to impose this bailout package will not only spike private sector lending, but also leave banks vulnerable to the stock market.

Also, recent actions of SBP suggests a blurring of responsibilities between the government and the central bank. Although these institutions are the most important policy making institutions in the country (and constitute the economic team), it is important to remember that there should be a healthy level of tension between the two since these institutions have conflicting end-goals. In other words, the government is primarily focused on growth (even on the back of subsidized credit or inflationary finance), while the central bank should prioritize price stability (even if it reduces economic growth). This is an integral part of the needed check on a government that can tax, borrow and print currency notes. When this distinction is no longer meaningful, there is a tendency to strive for high growth even if it unhinges macro economic stability. Unfortunately, this is what happened in Pakistan. In other words, the central bank had internalized the government's agenda over its own responsibilities. It 
appeared that (i) credit plan (ii) price stability as an important objective and (iii) autonomy of the central bank had lost their relevance.

\section{(XXV) Future Outlook}

1. If SBP wants to rein in credit expansion, it must continue to tighten liquidity

2. Increase in SLR may be required besides further increase in discount rate if banks' discretionary lending to the private sector does not ease off

3. Inflationary pressures are realized after a time lag, which means no immediate fall is expected as a direct response to monetary tightening

4. To contain dollarization, SBP may adopt a more aggressive stance in terms of increasing domestic interest rates

5. The increase in interest rates (and possible depreciation of the Rupee) will bring the economy back to macro equilibrium:

a. M2 growth will ease as private sector credit expansion slows

b. Inflationary pressures will start subsiding

c. The current account deficit will start narrowing

d. The gap between savings and credit will start narrowing, so that banks will not be running large maturity mismatches.

Credit expansion to the private sector is likely to be around Rs. 400 billion by end June FY05. If it does not ease during 2005-06, the exposure of the banking system will be so large that any shock (internal or external) could easily undermine the health of the banking system.

The advisable course for the State Bank for the next few years is to keep the rate of increase in money income (\% increase in GDP plus increase in prices) lower than the rate of monetary expansion by a margin that should enable it both to absorb a part of the monetary overhang (now about $28.0 \%)$ and allow only a modest increase in prices. This will not be easy. Yet holding the price line should be regarded as a non-negotiable objective by the Central Bank. 


\section{References}

Anjum Nasim 'Determinants of Inflation in Pakistan' Presented at LUMS.

Dr. Ishrat Hussain: 'Leading Issues Facing Pakistan Economy' Lecture delivered at the Centre for Development \& Democracy, Karachi on March 2000-Febraury 2003.

Dr. Ishrat Hussain, 'Economic Challenges Facing Pakistan' Lecture delivered at the Centre for Development \& Democracy, Karachi on $19^{\text {th }}$ January, 2001.

M. Ashraf Janjua, History of the State Bank of Pakistan, Volume III (1977-88) and IV 1988-2003), SBP Printing Press.

M. Ashraf Janjua, (edited) 'Monetary and Credit Control in Pakistan - A Regulatory Approach, Bulletin State Bank of Pakistan, March, 1989pp. i-xvi.

M. Ashraf Janjua, Central Bank and the Government SBP Printing Press, 1989.

Pakistan Economic Survey (various issues).

Rashid Amjad (Director, Policy Planning, International Labor Organization (ILO)' Geneva), 'Solving Pakistan's Poverty Puzzle: Who Should We Believe? What Should We Do?, PIDE, January 2004.

Richard Porter, 'Monetary Policy in the Economic Development of Pakistan' in Studies in Economic Development (with special reference to Pakistan) Agha M. Ghouse (Edited).

State Bank of Pakistan Annual and Quarterly Reports (various issues).

SBP Annual Report FY03.

Statistical Bulletin August 2004, SBP.

State Bank of Pakistan Quarterly Report 2004/05.

Sartaj Aziz, 'Was the 1990s a 'lost decade'? Dawn, Feb. 11, 2001.

S. A. Meenai, Money and Banking in Pakistan Oxford University Press. 